\section{Butt them no butts}

I an no expert on 'head-butting' but, intrigued by Michael Harmer's dislike of the apparently new coinage 'headbutt', it struck-me that butting, although done with the head, is not necessarily aimed into or at the head of one's adversary but may be the stomach, side or even back, whereas head-butting is surely always head-tohead contact, in which case perhaps the new verb is a useful variant, however fortuitously arrived at?

- Maurice West, Croydon, England

'Head-butt' is specifically a butt aimed at someone's cranium. I first heard the term used by Kent Walton, in a TV wrestling commentary. It is as much a technical, specialist term as 'nosedive', 'handstand' or 'stomach kick'.

o Paul Thompson, Shrewsbury, Shropshire, England

Re 'head-butting': the noun pedal seems insufficient to express the idea intended; the phrase 'foot pedal' is Gresham's latest currency.

- Frank Hoffman, New York City, New York, USA

\section{Sympathy over 'fulsome'}

I sympathise with $\mathrm{Mr}$ Kreindler (ET10) in his exposure of the misuse of the word 'fulsome'. Sadly, it is widespread on this side of the Atlantic, too. In May last year the Daily Telegraph printed an account of legal proceedings in which a law officer was quoted as saying 'I am instructed to offer a most fulsome apology'.
I was also interested in the article on Orkney Norn, giving 'chalder' as the local name of the oyster-catcher. The same bird is called 'tjaldur' in the Faroes, where it is the national emblem, and a protected species.

Finally, have readers noticed the prevalence of the awful 'up until', and does anyone think it can be defended?

English Today is a treasure-house. I look forward to the day when it becomes a monthly.

o N Hamment, Bolton, England

\section{Intrusive syllababbles}

You have recently published letters about errors and changes in English pronunciation. May I draw your attention to a far more evil and insidious habit - the intrusive syllable which is creeping into the language, particularly television English? A few weeks ago, one of Britain's betterknown broadcasters said that he was going to commentate a film. A few days ago, another well-known telecaster said that one of the channels would be giving a commentatory on a soccer match, and one of our better-known TV readers recently said that the Government had decided to implementate an Order under a certain Statute. I suppose that we shall have to put up with re-orientate which has been with us a long time, unless we can possibly re-orient ourselves to get rid of it.

I expect to hear before long that the well-known ecclesiastical building in the Brompton Road in London has become the Orotatory, that Mary Quant is giving a descriptatory of the latest fashions, that Muhammad Ali has developed a new method of relaxating, that the Poet Laureate has been deprecatorating some modern poem, that a well-known judge has commitated someone to prison for contemporation of court, and that we all have to be inoculorated against the latest infectionary. When is this obfuscatorianism to stop? You, Sir, must protectiforate us against all such additatives.

o A D Denton, Littlehampton, West Sussex, England

\section{Give it to us straight}

It is a truth universally acknowledged, as Jane Austen would have said, that in the world of sport the distinction between adverb and adjective has almost completely disappeared. Take, for example, the conversation between the $\mathrm{BBC}$ commentator and the world champion, $\mathrm{Mr}$ Steve Davis, during a recent televised snooker tournament:

COMMENTATOR How good did you play, Steve?

DAvis I think I played quite goód, but [paying tribute to his beaten opponent] Joe, he played marvellous, he played fantastic.

It may not be so widely appreciated, however, that the distinction is also lost in sporting analogies even when the subject matter in which they appear has nothing to do with sport. Thus, Mrs Thatcher, asked during the run-up to the election if the Conservatives had started their campaign too late, replied 'A long distance runner makes sure he finishes strong'.

As all the individuals concerned made their meanings perfectly plain, have become highly successsful in their professions, and earn a good deal more

\title{
Why 'gay'?
}

Not quite all my best friends are homosexuals, and even if they were I should still want to protest against the way they have appropriated and rendered virtually unusable in its former sense an English word which is not only attractive but also indispensable, as it conveys a subtle shade of meaning for which no other single word exists.

I am referring, of course, to 'gay'. Yes, one can understand, and strongly sympathise with, the desire to find a brief and simple descriptive word without pejorative implications. But why this word? Is it even appropriate, when nearly all of us know personally or have heard about so many homosexuals to whom gay, in the traditional sense, is the very last epithet one could think of applying? And think of the damage done to English poetry by this brutally insensitive and probably irrevocable take-over. To take two examples, both from justly famous anthology pieces:

A poet could not but be gay

In such a jocund company and:

All will be gay when noontide wakes anew

The buttercups, the little children's dower

But what I resent most bitterly is the ruination of one of my favourite passages: from Yeats's Lapis Lazuli (the whole poem is in fact spoilt, as 'gaiety' is its central theme). Ophelia and Cordelia, Yeats says, 'do not break up their lines to weep':
They know that Hamlet and Lear are gay;

Gaiety transfiguring all that dread.

All men have aimed at, found and lost;

Black out; Heaven blazing into the head;

Tragedy wrought to its uttermost.

There seems to me to be a kind of mystery about the speed and efficiency with which the take-over job was done: within less than a decade, was it not? There may have been protests, but I haven't seen any; and it is probably now too late for them. But this letter can at least do duty as a kind of obituary notice marking the death of a 'great and good' English word.

○ John Valder, Tunbridge Wells, Kent, England 
than I do, can someone please tell me whether any useful purpose is served by preserving the distinction between adjective and adverb? Does the difference enhance the language, or merely help to keep pedants employed? $\mathrm{I}$, too, wince when I hear the misplaced adjective, but am I being rational?

o John Elliott, UK Delegation to NATO

\section{An omalous athema}

To me, as to R M Blomfield (ET10: An omalous affair) omission of the indefinite article before words beginning with 'an' or ' $a$ ' is an anathema, a word the definitions of which are amplified in two of the four dictionaries reviewed in the same issue by Reinhard Hartmann. Both Collins and the Concise Oxford give the same example: 'he/it is anathema to me'. Are we cursing $a$ usage already legitimized?

o W F Kerr, Cringleford, Norwich, England

\section{Speaking for all of us}

I respond to John C Mullen's letter in ET10.

I am opposed to swearing because it's morally wrong and against accepted social standards. I was brought up to this and, like my parents did, feel very strongly about it. Class means little to me, in that I judge eggs by what lies under their shells. I feel swearing is only loosely linked to so called 'class'. Those who want to swear, swear, no matter what 'religion' they are.

As far as children in this go, those' considered 'up' compete favourably in the league with those 'down'. In either case it spells disgust, a fact that's so often voiced by people who are respectable . They don't like spitting either. I spoke for all of us when I wrote my article, published in ET7.

o Shirley E Peckham, New Milton, Hampshire, England

\section{The romanophone angle}

My congratulations on your survey of medium-sized dictionaries in ET10. I look forward to reading something on the more-than-medium-sized as well as on the specialized ones. As a translator, mainly from English, I may say that no general-purpose dictionary has served me better in twenty years than the unabridged Random House dictionary, invaluable above all for the usages and customs of both America and Britain, together with Partridge's Slang as well as Harrap's English-French-English Slang. Indeed, you certainly could not

\section{School Cheer (Progressive Style)}

A-root-toot-toot

A-root-toot-toot

We're from the Goose Egg Institute!

We are not rough

We are not tough

We don't believe in competitive stuff.

We learn ballet

And art through play

And how to be well-liked, each day.

We're taught to weave

And fly a kite

And make a good milk custard.

We cannot read

Or add or write

But, boy, are we adjusted!

\section{o Alma Denny, New York}

translate a non-academic history book, let alone a thriller, using any of the Oxford dictionaries from the Shorter downwards, though the Oxford Dictionary of Current Idiomatic English does at long last help!

With regard to Harry Morgan's letter concerning the lack in English of some equivalent to n'est-ce-pas, non e vero, etc.: Would that English lacked only this! What embarrasses most romanophones is, I think, the impossibility of addressing anyone in a conversation with the equivalent - as well as the social nuance - of Monsieur/ Signor(e), Professeur/Professor(e) etc. When in London, I regularly ridicule myself by addressing any man with $S i r$ (à la Johnson) every three words or so, it being repugnant to my nature to talk to someone who keeps being an amorphous 'you'.

With regard to David Crystal's article on singulars and plurals: Colloquial Italian seems to follow the same line of reasoning as with 'there's' and then a singular and its French equivalent. You may hear ' $\mathrm{C}$ 'e dei casi' instead of ' $\mathrm{Ci}$ sono dei casi', but 'C'e due/tre casi' would be unacceptable.

A request: Not even the bulky grammar of Quirk et al treats the irky problem of what I would call as introducing the false comparative. In expressions like 'as good as any', 'as good as they come', how does a native speaker distinguish between 'he is as good as every other is good' and 'he is the best of all'?

o Gianni Pilone-Colombo, Milan, Italy

\section{E's right, intee?}

Harry Morgan notes in ET10 the gap in English that is filled in other languages by nicht wahr, non $e$ vero, etc., but your cartoonist on p. 23 of the same issue uses our nearest equivalent with, 'So I told 'er, didn't I?' I think he ought to have spelt it dinneye or dinteye, because it is in the same series as innit or intit. It's part of a speech pattern that seems to have arisen in the early 70 s (or earlier) and is now perhaps slightly passé, and is purely rhetorical - or a verbal punctuation mark, a confirmation of a statement rather than a question:

'Where's that book?'

'Just put it down there, dinteye

It was like a plague among our comprehensive school and technical college students a few years ago, but as I said seems mercifully (?hopefully) to have passed. Oh, ri-i-ight!

- Paul Beale, Loughborough, Leicestershire, England

\section{On the up and up}

I find that among the English prepositions, which are such a curse to foreigners but which we regard as useful, the most versatile is $u p$. We add, back, call, dig, eat, fill, grow, hang, ice, jack, keep, let, melt, nail, own, pack, queue, rush, sell, take, use, vault, winch, yank and zip UP. There is only one $\mathrm{x}$-ception.

- Ronald Roper, Worthing, West Sussex, England

\section{The Story of Non-Saxon English?}

I am very surprised to read in The Story of English (cf. ET9, p. 41) that the first three words given as examples of Anglo-Saxon purism (steadholder for 'lieutenant', whimwork for 'grotesque', and folkwain for 'omnibus', all on $p$. 12) are attributed to William Morris. They were actually coined by William Barnes, whose Saxomania - as I described it in ET10 - was no doubt a source of inspiration for Morris himself

These words first appeared in 1830 , 1831 and 1869 respectively. After setting such words in the framework of 'a new romanticism', the authors of the $S O E$ condemn 'the absurdity of such usages'. But does Barnes really deserve the beating? Steadholder is the perfect equivalent of French lieutenant or Dutch stadhouder. If the case of whimwork is more debatable, folkwain is certainly a better formation than the cumbersome Latin dative omnibus ('for all'), which was borrowed almost simultaneously from French (1828) and English (1829). Strangely enough, Barnes's compound even heralds the one devised to name the most popular German car, Volkswagen. Why should 'Volkswagen' be felt as a good word in German and not 'folkwain' in English? Is it because wain is thought to be archaic or too poetical? And yet it can be found in wainwright, Charles's Wain 
(the Plough, in astronomy), and the Hay Wain, immortalized by Constable. That old English word, displaced in Standard English by its cognate waggon, a Dutch loanword, deserved to fare better.

- Jean-Marc Gachelin, Université de Haute-Normandie, Rouen, France

\section{Examples of splendid writing}

As a subscriber to your magazine from the very first issue, I would like to congratulate you on its continuing success. I have noticed that most of the contributors to $E T$ are employed in universities. They make the study of the language and its literature a life's work. These fortunate men and women must have remembrances of passages of English, both poetic and prose, which give them particular pleasure. I was wondering, therefore, if you might consider, as part of the magazine each quárter, publishing an example of splendid writing. I would expect that these illustrations would not only come from classical works, but would also be modern writings and could act as beacons to us ordinary folk. Thank you for your work on $E T$. It is a delightful moment for me when it arrives in the mail.

- Peter G Westlake, Vancouver, British Columbia, Canada

We would be interested to know whether others have similar views. $E d$.

\section{An Anglo view of the Scots}

I think I am unusual in having four English grand-parents and I am not ashamed of it. The article by Jane Marshall in ET10 on the use of 'Anglo' faintly irritated me. So far as I know, the Scots are largely of Anglian ancestry - what they would call Sassenach. That word and their language - even Lowland Scots - is of the same derivation basically as modern English. Of course they have a large Irish component on the west and Irish language in the northwest. Who knows about the Picts! As for England, there are an awful lot of Scots south of the border - more than in Scotland? There was a saying about the best view a Scot has! It is a pity she is so sensitive and that you support a slightly ignorant attitude. It is, of course, different for the Welsh and the Irish. I would understand her objection to 'English' covering all of the United Kingdom, but do not agree with the objection to Anglo.

○ Dr Eric Burkitt, Darlington, England

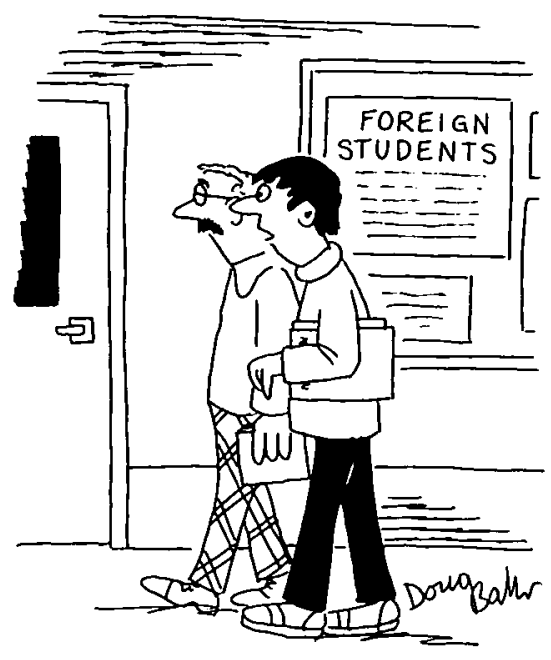

"It's I before $E$ except after $C$ ? That's wierd."

\section{Triply negated but doubly possessed}

May I offer some Scottish West Coast ingenuity, in the form of the triple negative, the double possessive and the inventive plural? When I was head waiter in a restaurant, on one occasion I was in the kitchen with the chef, and was asked in relation to the lateness of the staff's lunches: 'Does nane off youse know nuthin aboot nae denners? I answered, 'Er, no', and was greeted with, 'What dae yah mean - naw?' On one occasion I overheard a six-year-old child shout to its sister, at some distance, in a high wind, about a wayward puppy: 'Whose is its?' Lastly, there was once a waitress whose singular usage was 'breakfass', with the entirely reasonable plural 'breakfasses'. More power to your elbow.

- A A Rae, Greenock, Scotland

See also p. 43. $E d$.

\section{APpropriate for APostrophes}

Further to Greta Little's article 'The ambivalent apostrophe' (ET8, Oct 86), may I suggest that the cumbrous identification of the sign ' as APOSTROPHE be reduced to AP? Note how easy it is for someone to spell out $I$ 've as $I-a p-V-E$ and don't as $D-O-N-$ $a p-T$.

- Fred Bennett, Edinburgh, Scotland

Readers' letters are weicomed. ET policy is to publish as representative and informative a selec tion as possible in each issue. Such correspond ence, however, may be subject to editorial adaptation in order to make the most effective use of both the letters and the space available.

\section{A cloth fáinne in the Jailtacht}

You will perhaps be interested in some background to the attached copy of a page from Nuacht, the 4-page weekly published by the cultural section of Sinn Fein (see extract). The Fáinne ('ring') is worn on the lapel, tie or what-have-you. It signifies a wish to speak Irish as well as the ability to do so. Wearers will have demonstrated that ability in an informal aural examination. While in prison and despite a great deal of official hindrance, quite a number of prisoners have acquired the right to that distinction. Maybe you will have heard the term Gaeltacht for an area where Irish or Scottish Gaelic is spoken. From that word a pun has developed: 'the Jailtacht'.

On security grounds it has been ruled that the fáinne may not be worn by prisoners. Admittedly it would be possible to transform a metal badge of that nature into a tool or even a weapon, so that ruling was what might have been expected. Well over a year ago this organisation suggested that the security difficulty could be readily overcome by permission to wear a cloth fáinne which would be sewn onto the prisoner's garment. The committee that controls issue of the fáinne - and has no link with any political or sectarian organisation - approved a suitable design for a cloth fáinne. The Northern
Ireland Office, however, said no, proffering the excuse that approval of a cloth fáinne would be precedent for all sorts of paramilitary insignia.

$E T$ can and does take a pride in the spread of English as local language and/or lingua franca. At the same time, it ought to be an embarrassment that the language is being discredited in such a philistine manner at a local level by a branch of British government. Part of $E T$ 's scope is the linguistic struggle on these islands, a struggle which has not yet subsided. Theoretically, the Anglo-Irish Agreement recognises 'both traditions' as being legitimate. Clearly, in the case of the cloth fáinne, that is a concept that has so far failed to permeate through to the functionaries of the Northern Ireland Office.

- Pádraig Ó Conchúir, Press Officer, London Branch, Celtic League

From an undated copy of Nuacht, submitted by Pádraig Ó Conchúir:

Ar seisean: "While it is appreciated that the Fáinne itself is a cultural emblem, in the prison context its admission would undoubtably lead to demands from prisoners for other much less acceptable badges' (Nicholas Scott, Northern Ireland Office) 


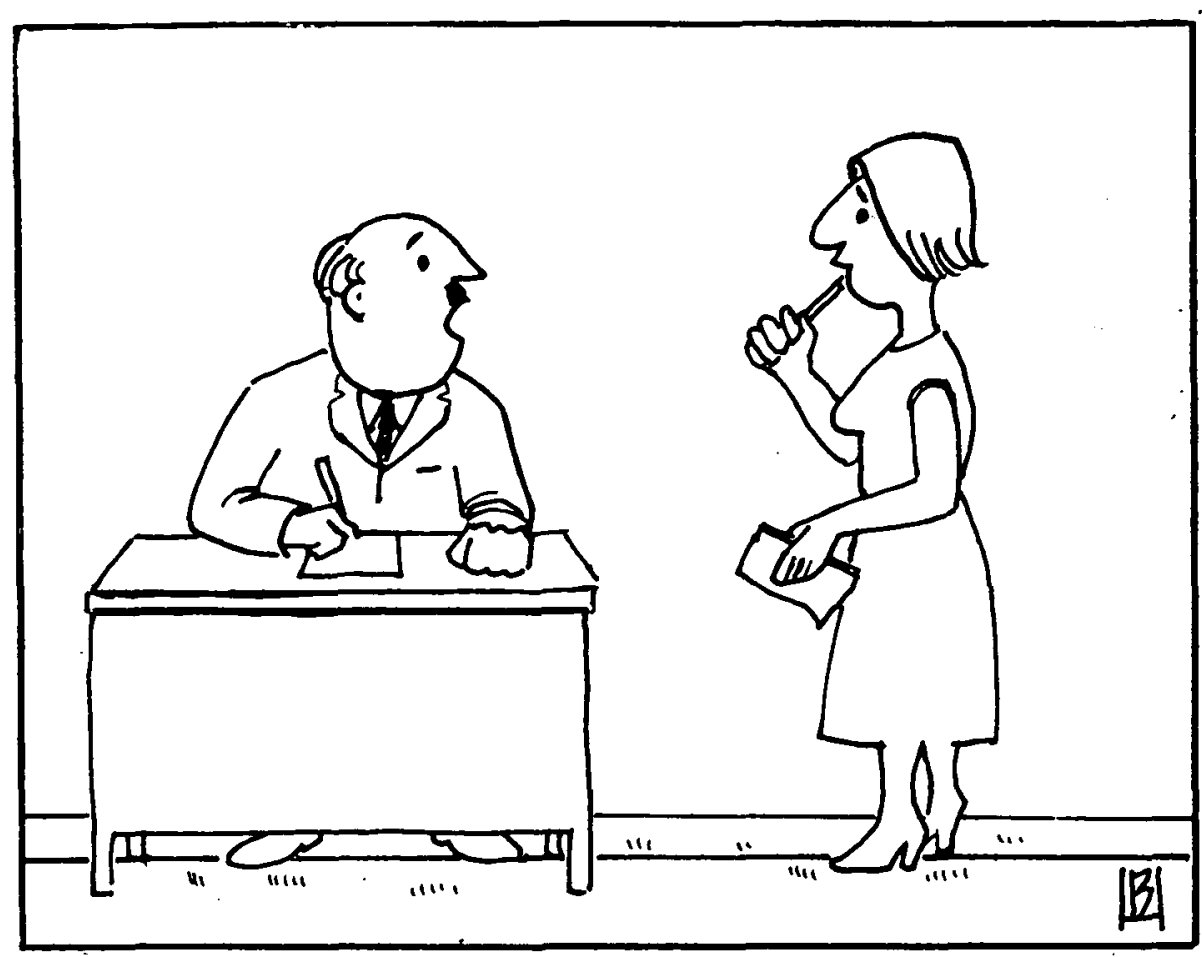

"I'm writing to my M.P. about the illiteracy of the applicants for our jobs. How do you spell illiteracy, Miss Finn?"

\section{Airspeak and Esperanto}

The press release designed to show that English has failed as the language of aviation $(E T 10$, p. 6$)$, is about as logical as the argument that since drunken drivers cause $40 \%$ of all road accidents, the best way of making the roads safer is to keep sober drivers off the road, since they cause $60 \%$ of all accidents! Presumably the point of the press release is to imply that Esperanto would do a better job than English; if so, then the argument runs like this: if one language causes problems in air traffic control, the solution is to add another language.

For Esperanto could not take over at once as the sole language of air traffic control; there would have to be an 'overlap period' ( 25 years? 50 years?), in which both English and Esperanto would be used. During this time a proportion of pilots and air traffic controllers would constantly have to be taken off the job for intensive training in Esperanto. Given the pressure under which pilots and air traffic controllers have to work, they would no doubt view this idea with a more than jaundiced eye, especially since the vast majority of them are very proficient indeed at English (I speak as one who has given extra English training to applicants for jobs as pilots with Swissair, to reach the extremely high standard of English demanded by that airline). And anyway, according to a manual widely used by private pilots in Germany to learn the English of aviation, Englisch im Cockpit, by Albert
Maier (5th edn., Stuttgart 1980, p. 326), English is a comparatively easy language to learn. So Esperanto would be a sheer waste of time.

The press release doesn't in any way prove that English has failed as the language of aviation - in fact rather the reverse. In the first place, five crashes in the twenty years 1960-1980 show that misunderstandings of English are one of the rarest causes of accidents, and secondly two of them have nothing to do with the use of English as such. In the Zagreb crash of 10 Sep 1965, the air traffic controller who panicked and shouted a warning in Serbo-Croat would presumably have found it as easy to use Serbo-Croat instead of Esperanto as he did to use it instead of English, and the use of ambiguous, non-standard instructions in the Tenerife crash in 1980 indicates only that the wrong terminology, not the wrong language, was used - one can be ambiguous and non-standard in any language, including Esperanto. Quite apart from the fact that Esperanto is not ipso facto likely to be used or understood any better than English, and so would not bring any advantage in the long run, the use of two languages in the overlap period would cost lives. I'd like to know the opinion of practising pilots and air traffic controllers on the idea of introducing Esperanto into aviation but I doubt it would be printable.

- Graham Pascoe, Ottenhofen, West Germany
My company is greatly concerned with effective communication. This is because the audiences for our meetings and publications are international. Those of us who are professional communicators therefore advocate the use of simplified English in all the company's day-to-day communication, both spoken and written. Walter Newport's letter in ET10 on the teaching of English as an international language highlights admirably some of the aspects of effective communication that we regularly address - mainly in our publications.

One interesting comment I recently received concerned a $\mathrm{PhD}$-level speaker, at an international convention, who could not understand questions put to him in ordinary English. He needed someone to interpret the questions before he could answer. He was Japanese. The lack of a sound grounding in ordinary English, on the part of those who speak to, or write for, international audiences, presents a serious threat to effective communication.

A good communicator masters the subject, the language, and the medium, and understands the audience.

PhD-level English in international communication is less a disease than a

Is International English likely to be used competently the world over in the next decade? Two letters in ET10 (The Failure of English', a letter as a press release for the Centenary of Esperanto, and one on the use of TEIL by Walter Newport from Japan), show that international understanding may depend upon an answer to that question. Whether you subscribe to the view that Esperanto will help us, or think that we must continue to use English but improve its use, it is clear that in the work with air traffic and in conferences or group meetings where there are international members there is an urgent need to be more aware of the minunderstandings that arise from the misuse of English.

The most frequent mistakes (between people of different nationalities) arise when we are speaking. Most students of English as a foreign language will have studied from texts in school or college, their learning has been formal, the grammatical basis has been sound, but their experience of everyday colloquial English speech is minimal. The same is true for learners of any foreign 


\section{ching English as an International Language}

\section{An IBM editor's endorsement}

symptom, which may have more than a single cause. For example, the speaker or writer may simply be ignorant of the nature of the audience, and may therefore not give due consideration to their needs, expectations, and abilities. He may make false assumptions about the audience, perhaps assuming that they all have PhDs in his subject, and that their depth of knowledge about the subject is akin to his own, so they will have no trouble with the language he uses. He may therefore be tempted to cut corners, leaving out this or that critical explanation. Or he could be trying to hide some ignorance of his subject by using unusual words as weapons of defence and daring anyone to challenge his meaning. He could even be trying to use the occasion as a platform to further his own career, with scant regard for true communication, for his audience, or for anything save personal kudos. I guess that many of us have come across this problem of the use of inappropriate language. And I guess that many of us have formed opinions about such 'communicators'.

An important point that $\mathrm{Mr}$ Newport does not bring up in his letter $(E T 10)$ is the psychological effect that such thoughtless communicators may have on people who are 'left out'.
In such situations, people tend to blame themselves for nor understanding. They may strain through hours of lectures or pages of books and be left feeling in some way 'inadequate'. They may withdraw, feeling personally deficient. But this is seldom warranted. The deficiency lies more often in the speaker or writer, whose job it is to communicate certain ideas. What these speakers and writers in fact communicate is an entirely different, and less desirable, message that underlies their words. This silent message could range from 'I don't really understand who you are or what you need,' through 'I'm insecure, so I have to use lots of jargon and long words to prove that I'm qualified,' and 'My subject is really so simple that I have to dress it up in fancy words,' to 'It's your job to understand me.' On the other hand, a poor communicator may simply be untrained in the use of the medium and nervous about appearing amateurish. Such communicators need education. To replace the worst offenders may not always be the ideal solution, for they really may have something important to say, yet lack the ability to express themselves appropriately.

Many companies recognize the need for education in audio-visual presentations, writing, graphics, and associated subjects, and offer suitable courses for employees. But many other companies reject such training because of its cost. The true cost of inadequate training, however, may far exceed the cost of proper training. Whenever a company tries to communicate publicly, it puts itself on trial. And when it buries its message in a grave of strange words, the audience judges it severely and reacts negatively, withdrawing from the words, from the ill-explained idea (perhaps a new product), and from the company. The company is then likely to lose both prestige and customers.

Communicators must know their audiences - not the ideal audiences of their imaginations, but the real audiences of their words. They must be at one with their audiences at all times. To leave any listener or reader with a sense of personal inadequacy, because he failed to understand a message, is perhaps the greatest crime a would-be communicator can commit. And the psychological effect on the listener or reader may indeed be far-reaching.

- Ian Wright, Editor, IBM Product Development Center, Vienna, Austria

\section{Awareness is all}

language, but English, unlike any other language, is used by non-native speakers for purposes that go beyond the bounds of tourism - studying technology and science, international conferences, telecommunications and air travel. Mistakes of language understanding in these fields have serious repercussions. The mistakes occur because the spoken English is different in kind from the literary variety, there is a much wider disparity between the two than in many other languages. There is also a lack of competent oral teaching, as $\mathrm{Mr}$ Newport said; teachers deal more with reading and writing and less with listening and speaking. Amazingly this is still so, in spite of much research and publicity for oral work. Little practice is given in tone, elision, abbreviated colloquial use, idioms, or widely-used slang. How then can students manage in situations of daily work? Scholarly people who are non-natives of the English tongue, highly qualified in a particular study, trained in English, are often astonished at their inability to understand spoken English.
The Briton using his/her own language in an international way would do well to reread Fraffley Suite and The Krek Weight Spik Bristle in order to be reminded that to even a competent foreigner your greeting may seem to mean 'Higher do in?' or 'Mayor yosk yon nem?' or 'Sedger sin swif sinew' (It's ages since we've seen you) or 'What syaw gull call?' (What's your girl called?). The above utterances are totally changed from their written counterparts because of the two phenomena of stress and the neutral vowel [ə]. The unaccustomed listener reaches a nonsense result. Having bravely tried to memorise what she was taught, pick up the carelessly flung vowels, transliterate them into recognisable or possible English words, the hapless foreigner is then far behind for the next piece which may be such a common idiom as 'We'd better get a move on', or 'Well, it's getting on and I must be off'.

I am not advocating that we spend all our time as teachers of EFL or ESL on practising localised slang or dialect. If we are genuine in our intentions to use
English as an international language we must eschew such usages when we are speaking in international situations. We must recognise the needs of the participants and immediately, unnoticeably, make the effort to switch to a simpler vocabulary, non-slang, uttered with more care than many native speakers commonly use. I agree with $\mathrm{Mr}$ Newport that the responsibility lies with native speakers. Teachers, however, must spend more time emphasising the slurred elided effects in English, making their pupils pronounce 'received pronunciation' informally, so that they will then understand it when they hear it. Thus, they should practise: 'Whatcher doing?' as well as 'What are you doing?'; 'He mayev bin bitn by a dog' as well as 'He may have been bitten by a dog'! This experience will then have acquainted the student of English with everyday informal utterance to some extent, so that they may be able to avoid some pitfalls. For each of us in language study, awareness is all.

- Mrs B Ryder, Clifton, Bristol, England 
Few young people can resist an invitation to appear on the amateur stage. Exciting dreams are dreamed as one remembers famous players who began that way.

A vivid memory of one of my earliest appearances still brings, after many decades, a tremor of embarrassment. I had been asked, in an adaptation of George Eliot's Adam Bede, to play Squire Donnithorne, the wicked seducer of poor Hetty Sorrel. In a scene dominated by Adam and Hetty, the rest of the cast had to simulate quiet conversation in small groups upstage. Until then, nobody had initiated me into the magical qualities of rhubarb, and as we stepped forward into the limelight I uttered, loud and clear, the immortal words, 'Righto, Mrs Poyser.'

Before the next performance the producer took me aside and gently whispered, 'No rightos tonight, young man.'

British TV is supreme in producing period plays and in adapting from the classics, but inevitably many writers and producers are young. The task of the producer is less fraught with pirfalls than that of the writer. Visual anachronisms are usually easy to avoid - overhead wires, TV aerials, white and yellow lines, cats' eyes, modern pillarboxes - though the experts among the viewers, the steam-train buffs, the vintage car enthusiasts, the connoisseurs of military uniforms, are always waiting, ready to pounce. Risks of verbal solecisms present a far greater problem, for it is all too easy to assume that a word or an expression which is part of the ready coinage of one's daily life has been in circulation for fifty, a hundred, two hundred years.

How else can one account for the actor playing the friend of young Dickens being given the words 'I'm afraid I'm not with you, Charles' (Dickens of London, ITV)? Or the use of 'Belt up!', a fierce phrase which has become popular only during the past twenty years, in an episode in When the Boat Comes In (BBC), set in the 1920s? Or two expressions which have come into use only since the last war - 'You can say that again' and 'You could have fooled me' - being uttered glibly in Love for Lydia (ITV) from the same period?

A more blatant example from that thrilling series based upon adventures in Victorian merchant steam-ships, The Onedin Line (BBC) made the older viewer jump: 'There's no skin off my nose'. This unattractive image belongs entirely to modern times.

The book Tom Brown's Schooldays appeared in the $1850 \mathrm{~s}$, but in the version on our television screens we heard two purely 20th century exclamations - 'Cheerio!' and my old friend 'Righto!'.

An early episode in the series based upon the life of King Edward VII (BBC) showed us the young heir to Victoria's throne being asked by his stern tutor 'What was the date of the Battle of Austerlitz?' and replying, 'Eighteen - OH - five, Sir'. As some veterans will remember, the introduction of 'nought' and, later, ' $\mathrm{OH}$ ' in spoken numbers and dates was first adopted during the present century, becoming common only as the use of the telephone spread more widely. In the 1850 s the young prince would have replied, 'Eighteen hundred and five, Sir.'

Many traditionalists among us find a new and increasingly popular use of the word 'hopefully' irksome, but while we may bow to the inevitable, knowing that language cannot stand still, we must refuse to accept that the word would ever have been uttered in its modern guise by the Prince Consort, as portrayed in ITV's Disraeli.

While the oldie can usually rely upon his instinctive reactions, the feelings-inhis-bones, in spotting that a particular word or phrase is out of period, he may occasionally find himself making a surprising mistake. Although all the gaffes in the foregoing examples have been confirmed by reference to an unimpeachable wordsmith - the late Eric Partridge - that same authority declined to uphold one's case against The Pallisers (adapted by the $\mathrm{BBC}$ from Trollope). Here one character says, 'I propose to conclude with a nice long hike.'

'Aha!' we exclaim triumphantly. 'A glaring blunder, if ever there was one!' But wait. Partridge tells us that 'a hike', meaning 'a long walk, especially for exercise or pleasure' was in common colloquial use in this country in the middle of the nineteenth century; then it faded out, cropping up a little later in the USA, whence it returned to these shores during the $1920 \mathrm{~s}$. It's a fascinating game. Is it possible to foresee a time when we shall find, included in that long list of credits which, as a programme ends, chase one another up the TV screen, a new technician: 'Geriatric Consultant'?

o Eric Wyeth Gadd, Bitterne, Southampton, England

\section{Claiborne answers Cassidy}

Frederic Cassidy, understandably, dislikes my comments on DARE. But in seeking to rebut them, he has confirmed nearly everything I said while erecting and demolishing several straw men: things I didn't say. Some specifics:

- He says I criticised DARE for excluding slang; I didn't. Having contributed to several slang dictionaries, I'm well aware that the field has been preempted.

- He says I faulted DARE for excluding occupational lingo; I didn't. My complaint was rather that it included non-regional terms from certain 'widespread' occupations (e.g., mining, railroading) but omitted regionally variable ones from others equally widespread (e.g., oil-drilling, crime, law enforcement). I'm happy to learn that DARE includes cherry top (police vehicle); too bad it missed the nearly synonymous 'bluebird' (Mass.) and 'black-and-white' (Calif.).

- He says I've 'misread' his figures on the geographical distribution of his informants - but his corrected figures still prove my point: e.g., both Atlanta (population $>1,000,000$ ) and

Marshalville (population $<10,000$ ) got one questionnaire. And no misreading can explain the total exclusion of more than a dozen major American cities, or the pervasive rural bias of the questionnaire itself.

On my central point, DARE's overemphasis on old-fashioned rural language, Cassidy seems to want it both ways. He insists that American dialectologists do study urban speech (yes, a few of them), and that the DARE questionnaire did include 'questions on urban features' (yes, a 'scant dozen). He then justifies DARE's evident biases on the ground that all word geographies 'concentrate on rural language and . . . elderly informants'. Indeed they do - and that's just what I criticised.

In focussing on ruralism, of ten archaic, DARE has, as Cassidy says, provided 'data of great value to etymology and linguistic history'. What it hasn't provided is a comprehensive dictionary of American regional English - past and present, rural and urban, young and old, general and occupational. I consider this a serious fault, and I said so. Maybe forthcoming volumes will change my mind, but given the methodology and, yes, prejudices that underlie the work, I'm not holding my breath,

- Robert Claiborne, Truro, Maryland, USA 


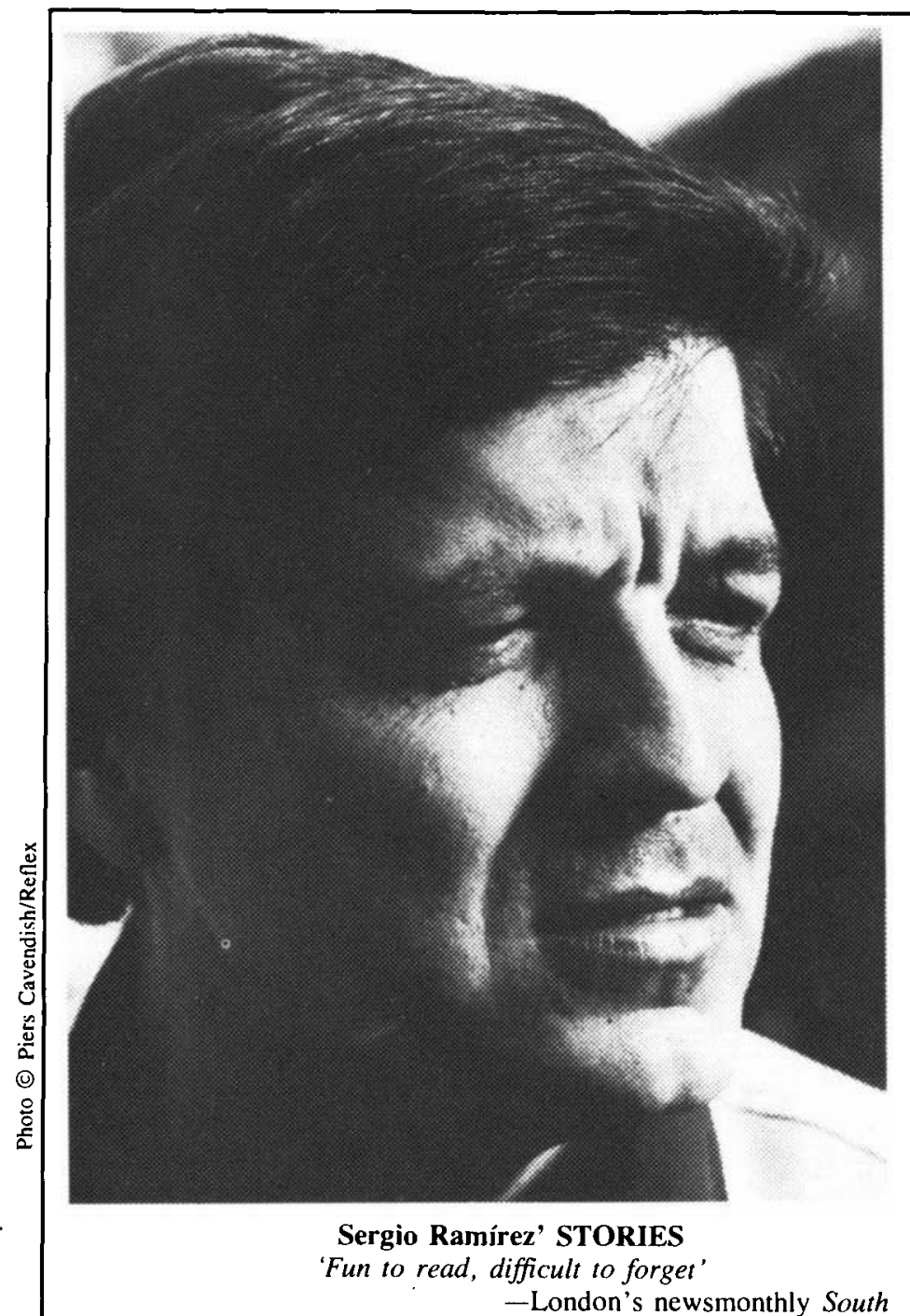

\section{THE \$100 MILLION SHORT STORY COMPETITION Or, Can George Bush Write Fiction?}

SERGIO RAMIREZ, Nicaragua's vice president and master storyteller. As man of action, he leads a revolution. As artist, he writes quality fiction: 'a product not even great navies and blundering giants can embargo' says the L.A. Times of his work. Now Readers International (RI) brings you his stories in English-lively reading for anyone with an interest in Central America or in good literature.

The N.Y. Times Book Review calls them 'biting and satirical short stories'.

- Ramírez' bodybuilding fanatic, baseball players, weatherman, down-and-out Santa Claus serve in no propaganda army.

They are the comic, unheroic figures of an honest, humane insider's view. 'The stories are masterfully told,' says Publishers Weekly, 'and will reach readers' hearts.' Blundering giants can't stop a good story... Not even with $\$ 100$ million.

Begin your subscription to RI's world literature series with Sergio Ramírez' STORIES. Every other month you will receive a new hardback volume - the best of world fiction-at the subscriber price of $£ 4.75+75 p$ postage.

Forthcoming selections include the modern Haitian epic, Cathedral of the August Heat; The Laughing Cry, a searing Congolese satire on the Great African Dictator; and $A$ Cup of Coffee with My Interrogator, ironic short (underground) fiction from Czechoslovakia.

RI subscribers have already helped publish some of the finest of today's literature from South Africa, Chile, Poland, the Philippines, East Germany, Lebanon, China, Brazil, Japan and elsewhere.

Subscribe now for a good read and help bring today's most gifted writers into Englishall at a very modest price.

\section{- READERS INTERNATIONAL \\ 8 Strathray Gardens, London NW3 4NY}

Please begin my subscription to RI's series with Sergio Ramirez' Stories at the $£ 4.75$ subscriber price plus $75 \mathrm{p}$ for postage. Send RI's latest book at the same price every other month. At any time I may cancel simply by writing you.

\section{NAME}

ADDRESS

TOWN

CODE

COUNTRY

$\square £ 5.50$ ( $£ 7$ overseas) to Readers International is enclosed.

(North American subscribers, please send

US\$9.95/Can\$12.50, incl. postage, to RI Subscriber Service Dept., P.O. Box 959, Columbia, LA 71418.) SPECIAL SAVINGS: Prepay a year's

subscription for six books at $\$ 3.75$ each plus 75 p postage.

$\square$ I enclose my payment for $£ 27$ inland, US\$48, Can\$58, $£ 35$ sterling elsewhere. 


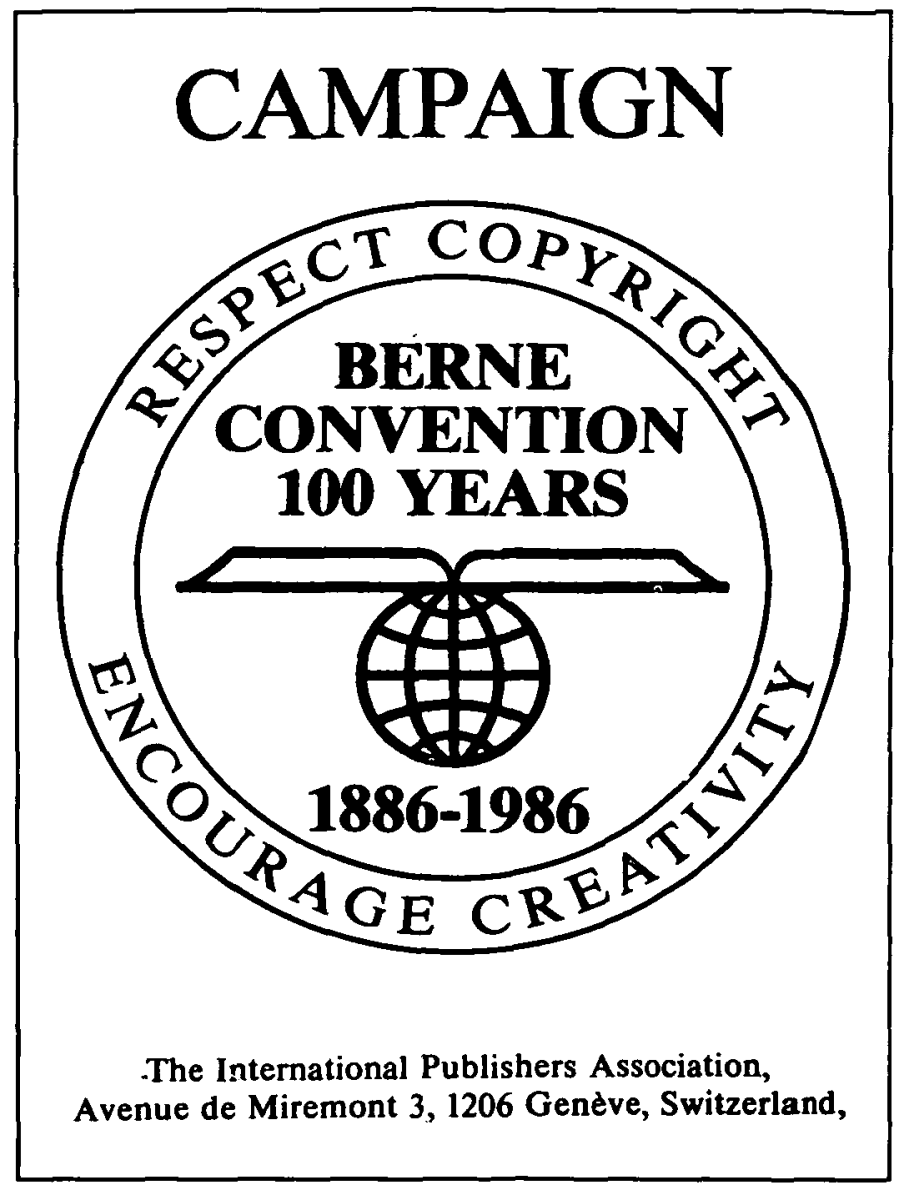

\section{Come in, customer! Do you read me?}

How often do your customers misunderstand your printed messages? We specialise in making sure they don't. We rewrite and redesign forms, leaflets, legal documents (such as insurance policies), instructions, medical labels and package inserts. We work for companies, local and national government, and health authorities.

We provide any or all of these services:

- appraisal - editing and redrafting

- replanning and redesign typesetting and artwork camera-work and printing

- plain English training.

It's a fast, professional, confidential service at a reasonable cost. Distance is no object.

Contact Martin Cutts or Chrissie Maher, Language \& Layout Service (Plain English Campaign), Vernon House, Whaley Bridge, Stockport SK 12 7HP Tel (06633) 454I.

\section{We're plain English. Fly us for clarity.}

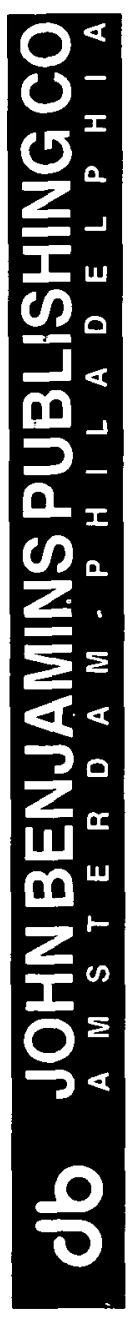

\author{
EDITORIAL ADDRESS \\ Manfred Görlách \\ Universität zu Köln \\ Englisches Seminar \\ Albertus-Magnus-Platz \\ D-5000 KÖLN 41, Germany
}

ENGLISH WORLD-WIDE

A JOURNAL OF VARIETIES OF ENGLISH AROUND THE WORLD

\section{EDITORS}

Manfred Görlach (University of Köln)

Richard W. Bailey (Ann Arbor)

Loreto Todd (University of Leeds)

\section{AIM AND SCOPE}

English World-Wide contains scholarly articles, research in progress, short annotated texts, bibliographies and reviews on regional and social variation in English around the world, such as:

English as a native, second, additional and international auxiliary language; descriptions of structures of Englishes; pidgin/ creole/broken English. Social significance, attitudes, evaluations, domains of varieties of English. Emerging standards and usage problems, language planning, bi-/multilingualism; language communities. Types of texts and their uses (including the media, administration, the schools; literary uses); types of interference and code mixing.

Although teaching problems are normally excluded EWW provides important background information for all those involved in teaching English throughout the world.

Institutions $\mathrm{Hfl} .120,--/ \$ 48.00$ plus $\mathrm{Hfl} .15,--/ \$ 5.60$ postage

A sample copy is available on request.

Individuals $H$ fl. $\quad 60,--\$ 24.00$, postage included (prepayment required)

\section{PUBLISHER}

John Benjamins Publishing Company

P.O.Box 52519 - Amsteldijk $44 \cdot 1007$ HA AMSTERDAM - Holland / One Buttonwood Square - PHILADELPHIA/Pa. 19130 - USA 露 $(020) 738156$

实 (215) 564-6379 